\title{
ИСТОРИЯ ПРОИСХОЖДЕНИЯ СЛОВ: КАВКАЗ, КЫПЧАК, КАЗАК, ЧЕРКЕС
}

\section{HISTORY OF THE ORIGIN OF WORDS: CAUCASUS, KIPCHAK, COSSACK, CIRCASSIAN}

\section{A. Dzhumaeva}

S. Menglieva

Summary: The relevance and significance of the study is explained by the fact that in Nogai linguistics, many historical names that are recorded in Russian chronicles have not been sufficiently studied. The relevance of the research topic is due to the premises associated with the history of the Nogai people. The Türko-Nogai onomastic system, recorded in the Russian chronicles, was formed in complex geographical, historical and linguistic dialectal conditions. The aim is to examine the features of the word-formative elements of the Nogai language, a historical and linguistic analysis of the Türko-Nogai names, which are recorded in the Russian chronicles of the period of the 9th-16th centuries. Comparative - contrastive analysis was used in the analysis of words. With the help of these methods, the phenomena of linguistic interference were identified. In-depth reading allows you to more fully identify the representation of sounds similar to them sounds. And also to understand the essence of its historical origin.

Keywords: nogai language, dialect, word formation, Kypchak, steppe, onomastic system.

\author{
Джумаева Айбике Агоевна \\ К.филол.н., старший преподаватель, Сургутский \\ государственный университет \\ dzhumaeva_aa@surgu.ru \\ Менглиева Сальсет Зейнулаевна \\ Учитель, Новокрестьяновкая школа
}

Аннотация: Актуальность и значимость исследования объясняется тем, что в ногайском языкознании многие исторические названия, которые зафиксированы в русских летописях, не достаточно изучены. Востребованность темы исследования обуславливается предпосылками, связанными с историей ногайского народа. Тюрко-ногайская ономастическая система, зафиксированная в русских летописях, формировалась в сложных географических, исторических и лингвадиалектных условиях. Целью заключается в рассмотрении особенностей словообразовательных элементов ногайского языка историко-лингвистический анализ тюрко-ногайских названий, которые зафиксированы в русских летописях периода IX - XVI вB. При анализе слов использовался сравнительно-сопоставительный анализ. С помощью этих методов были выявлены явления языковой интерференции. Углубленное прочтение позволяет более полно выявить представление звуков сходные с ними звуки. А также понять суть его исторического происхождения.

Ключевые слова: ногайский язык, диалект, словообразование, кыпчак, степняк, ономастическая система.

«гора» означает «кох».

В Бехистунской надписи Дарай I перечисляет народы, которые платили ему дань, среди которых можно встретить такие названия как «каспии», «саки» из 11 - го и 15 го округов Персидской державы. Самого слова «Кавказ» там нет, но сопоставив соседние округа можно вычислить местоположение этих 11, 15 округов: от «армениев до Понта Евксинского» - 13 округ, острова Эритрейского моря - это 14 округ, 16 округ - это «нарфяне, хорезмии, согды» - уже Средняя Азия, значит 15 округ должен быть между Средней Азией и Понтом (Чёрным морем), а это нахождение местности Кавказ. Значит «каспии» и «саки» 15 округа жили на Кавказе.

Из источников Константина Багрянородного известно, что бассейн реки Кубань в X веке называется «Кассахия». По истории Древней Руси князь Мстислав Владимирович покорил «касогов» в 1022 году в этой местности.

А также из письма хазарского кагана Иосиф пишет испанскому министру Хасдаю, что южная граница его 
страны проходит по «стране Каса».[3] Таким образом «каспии» Дария I, «Кассахия» Константина Багрянородного, «касоги» русской летописи, страна «Кас» хазарского каганата имеют корень «касс». Греческое слово Caucasus тоже имеет корень «саs»(кас). В ногайских именах очень часто встречается корень «касс»: Кастувган, Касболат, Касмамбет, а также в названии моря - Каспийское море.

Черкассы, Кичикасы на Днепре делая вывод, что народ «касс» жил на Кавказе и что «касоги», «каспии» - искаженные варианты сделанные персами и русскими названия степных кочевников «кассаков». От частого употребления этого слова начиная с X века оно стало произноситься тверже «казак». В 1936 году Советская Россия туркестанских казаков переименовала в «казах», чтобы не путать с казаками - христьянского происхождения.

Кыпчак, азок, черкес.

Раскрытие тайны образования слова «казак» тянет за собой цепочку, не менее загадочных слов, как «кыпчак», «asoc», «черкес». Саков на евразийском просторе было великое множество. Источники средневековья, чтобы уточнить, о каких саках ведут повествование, стали их определять по разным признакам кавказских саков они называли - «кассаки», азов на Дону (asoci) - азсаки, принявших иудейскую веру хазаров и живущих в Крыму - «крымчаки», а многочисленных азиатских саков стали называть «коьп саки» (многочисленные саки). Слово «коьпсак» с подачи персов превратилось в «Дешт кыпчак». Там, где не было персов, например в Гагаузии, до сиз пор сохранилось название города «Копсак» слово «кыпчак» встречается в восточном Тюркском каганате еще в VIII веке на стеле полководца Культегина как «кыбчак», но тогда это слово вероятно означало «куьбчак», что равносильно племени сак. После разгрома Хазарии русскими князьями, ее народы стали самоопределяться, как обычно бывает после распада больших империй (последний факт - распад СССР на множество государств, распад Золотой Орды на множество ханов...). Так на территории бывшей Хазарии появились Баскунчак (главные куны и саки), кыпчаки, иудеи бежали, кто в Крым, кто в Киев, в Венгрии - Яскуншак (ясы - асы, куны - куманы, исак - сак). Г. Закаталы (Сак дала) в Азербайджане, («дала» - степь). Слов с корнем «сак» и «касс» на карте России и соседних государств - большое множество, всех не перечислить.

Название Черкес тоже возникло с появлением слова «казак». Город Черкассы на Днепре был основан в 1282 году изгнанными из г. Ральска «Черкасами», назвавшими себя казаками (это были потомки летописных «касогов»), как записал Карамзин А. в Примечании к истории Государства Российского 1832 г. Т.1, с. 388. Слово «Черкес»- это сокращенное «чериккас» («черик» - часть, четверть). Вполне понятно, что город основали все кассы, а только часть. Часть города Черкасс до сих пор называется «Казбет», (сторона казов) написано М. Глуховым - Нагайбеком. Оставшихся на Кубани и Пятигорье касов тоже стали называть Черкасами - Черкесами. Ниже Черкасс по Днепру есть городок или поселок Кичикас (младшие кассы), в Румынии есть город Биказ (би, бий - господин) «господа кассы». Особенно много топонимов с корнем «касс» на Кавказе, в Грузии: гора Каз(с)бек, города Казбеги, Казрети, в Азербайджане - города Казак, Казэли, Казли - в России город Казань, Каспийское море, ногайское село в Дагестане Карагас, народы: казак, казах, каракасы, крагаши, ногайцы - казы.

Некоторых смущает превращение «касс» в «каз», ведь это происходит в течение 2500 лет на огромной территории. Мы полагаем, что арабское «газы» тоже способствовало этому влиянию, а также слово «хазар» первоначально было «касар», так как в VI веке были популярные термины со словом «ар» (древнетюркский народ), например: булгары, сувары, бавары). Кроме того, слово «каз» на всех кавказских языках означает «гусь», у тюркских народов еще означает «воин». До сих пор ногайцы подзадоривают своих 9 - 10 месячных малышей словами «казай, казай, каз - болшы!» (стань на ножки, стань воином). А про никчемных братьев говорят: «ага - инли конъыр каз, агасыннын басы таз, инисиннин коьти пок» (Старший брат и младший брат - серые гуси (залётные вояки), только старший брат уже лысый, а младший еще пачкает коленки».

Первоначальные казаки и черик кассы были выходцами из Северного Кавказа, вероятно из разных племен потому, что словом «казак» их называли соседние народы, а потом ее родичи стали говорить «казак шыгып кетти» - получилось человек уходил на поиски заработка, то есть слово «казак» имело образ профессии, потому что отряды воинов с конца XIII по XVI век в Золотой орде назывались «казаками». Воины золотоордынского темника Ногая назывались казакми. После гибели Ногая его подданных золотоордынский хан Тохта переселил в Поволжье, оставшиеся в Северном Причерноморье казаки подались на Днепровские пороги, где создали Запорожскую Сеть. Из нижнего Поволжья переселенцы (казаки) частично попадают на службу в Канешва Сред Азии.

Кроме всего этого в русских народных сказках слова «куны» (кув - лебедь) и каз (гусь) нашли отражение под образом злой силы - «гуси - лебеди» крадующие детей. Этот образ основан на реальных событиях: ни хазары, ни куманы, ни их соседи - славянские народы - не были ангелами, совершали нападения друг на друга для захвата добычи. В связи с этим промыслом за словом «казак» закрепился смысл «воин». По нынешнее время существу- 
ют термины «конъыр каз» - серые гуси (залётные воины), «акказ - воин аристократического происхождения.

B XVI веке, когда Ногайская Орда распалась, особенно в 1556 - 1557 годах, когда золотоордынского хана Юсуфа убил младший брат Исмаил и провозгласил себя ханом, не согласные с его решением ушли от него. В эти годы в Поволжье была страшная засуха и эпидемия чумы. Большая часть ногаев племени «алчын» со всеми их родами Алаша, Адай, Телеу, Черкеш, Берис, Тама, Тана, Чомеке ушли на восток к киргиз-кайсакам и образовали там Младший Жуз.

С распадом Золотой Орды набеги кочевников пошли на спад, безработные степные рыцари нанимались азиатскими правителями и западными государствами: Литвой, Польшей, Московской Русью. Степняков принимали охотно, наделяли земельным поместьем, дворянским званием. Среди названных государств выходцы из степи составляли заметную часть (самые богатые дворяне царской России - князья Юсуповы и Урусовы).

Так в XVI веке народы Золотой орды распались на множество мелких ханств. Вольнолюбивые степняки разрушали родовые и племенные устои предков, каждый выбирал свой путь. Были и такие, что остались без семьи, без родни, без веры в завтрашний день. Такие бывалые воины уходили в ближайшие леса, броды где можно было ограбить проезжих купцов, то есть в лесах Дона, Терека, Волги появились казаки - разбойники[1]. Существовали они стаями - ватагами. Российская официальная история говорит, что это были беглые русские крестьяне. Русские крестьяне переместились на окраины Руси во времена Ливонской войны, смутного времени (1600 - 1612 гг.), Церковного раскола (1648), то есть с усилением крепостного права и попадали они в уже существовавшие казачьи отряды. Имена казачьих атаманов, казачьи порядки, термины указывают на их происхождение, «Сары Казман» - имя первого казачьего атамана, заключившего договор с Иваном Грозным, следующий - Ермак, а в Запорожской сечи - Мамай. Все имена и прозвища легко переводятся на ногайский язык: Сары - жёлтый, Казман - человек из казов, Ермак - рвущий, Мамай - ласкательный вариант имени Мамбет, Мухаммед. Казачий круг - по ногайский «орта», слово «орда» произошло от слова «орта». Золотая орда - означало «Алтын орта» - «золотой центр» называлась резиденция хана. Слово «есаул» произошло от слов «иеси» - хозяин, «аул» - род, получается, что «есаул» - хозяин рода или же «сотник» потому, что род мог выставить больше или меньше сотни воинов - казаков. Таким образом, атаманы сохранили знакомые навыки, организацию создали по известным им золотоордынскому опыту.
XVI века Досмамбет Азаулы в стихотворении «Косайым» говорит о встрече Каза приветствующего юного богатыря Косая в городе Азове.

Последние кочевья казов были зарегистрированы в 1836 году близ города Астрахани а ныне представители народа «каз» есть в ауле Канглы, Ставрапольского края, в Ногайском районе КЧР, в аулах Карагас.

О появлении казаков на берегу Терека, исследователь Кизлярщины Д.С. Васильев в своей книге «Очерки истории низовьев Терека», пишет, что казаки селились на свободных, никем не занятых землях, то и процесс этот происходил мирным путем. Этот благодатный край никогда не был «свободной землёй». Где не копни, повсюду найдёшь останки людей. Бесчисленные курганы никто не изучал, они ушли под мелиорацию в 60 - е годы XX века. Ведь устье Терека - один из самых мелиоративных районов мира. Лишь однажды профессор Грозненского университета Виноградов В. Б. производил раскопки у села Коби и аула Каршыга. В первом погребении бронзового века (4 тысячи лет назад) был похоронен человек с глиняной посудой. Во втором погребении были останки знатного скифа, ограбленного в древности, но сохранились останки бронзового панциря и наконечники стрел. Следующее погребение принадлежало молодой «сарматке» с предметами для гадания, зеркало и другие предметы. Четвертое захоронение принадлежало степняку - воину, о чем свидетельствовал согнутый кончик, лук со стрелами «атрибуты времён Золотой Орды - XIII - XIV века, так как с принятием ислама в Золотой Орде стал меняться и похоронный обряд. Этот степняк был похоронен в духе Тенгрианства.

По свидетельству профессора В.Б. Виноградова «в древней и средней истории участок Затеречья выглядел «белым пятном», а то и своего рода «полигоном» для всяческих околонаучных фантазий.

Развитие русского казачества описано в трёхтомном издании «История казачества» Гордеевым А.А.

Таким образом, слова «казак», «черкес», «Кавказ» родственные слова с корнем «касс». Слова «кыпчак», «азок», «крымчак», «Баскунчак», «Яскуншак», «Саха», «сагайские» татары имеют корень «сак» (древнеперсидское название степняков - кочевников евразийских степей).

С течением времени потомки касов и саков влились в состав многих евразийских народов. Генетический анализ крови наших современников показывает насколько перемешались наши предки и являемся родственниками. Каждый разумный человек должен знать своё происхождение, уважать соседние народы, так как мы обречены жить на одной территории, в одной стране. 


\section{ЛИТЕРАТУРА}

1. Васильев Д.С. Очерки истории низовьев Терека. Махачкала: Даг.кн. изд-во, 1986. - С. 16.

2. Глухов М.С. Судьба Гвардейцев Сеюмбеки. - Казань: Ватан, 1993. - С. 12 - 84.

3. Керейтов Р.Х. Ногайцы. Особенности этнической истории бытовой культуры. - Ставрополь: Сервисшкола, 2009 - С. 117.

4. Плетнева С.А. Хазары. - Москва, Наука, 1976. - С. 10.

5. Тынышпаев М.Т. Материалы к истории киргиз-казакского народа. - Ташкент: Восточное отделение Киргизского государственного изд - ва, 1925.

(с Джумаева Айбике Агоевна (dzhumaeva_aа@surgu.ru), Менглиева Сальсет Зейнулаевна.

Журнал «Современная наука: актуальные проблемы теории и практики»

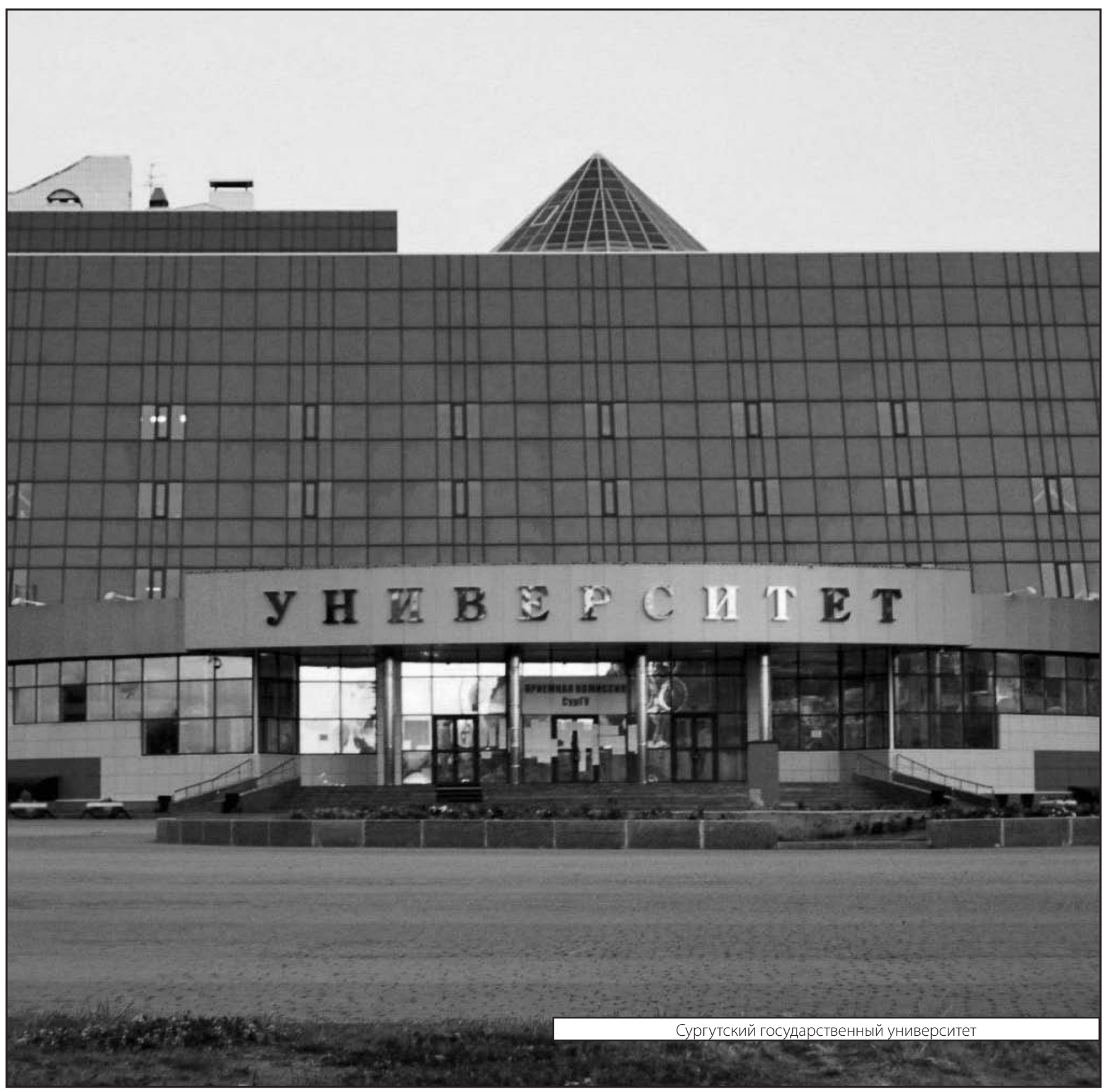

